\title{
РЕЗУЛЬТАТЫ ИЗУЧЕНИЯ ТЕРРИГЕННЫХ ПОЛИМИКТОВЫХ КОЛЛЕКТОРОВ ВЕРХНЕПЕРМСКИХ ОТЛОЖЕНИЙ МЕТОДАМИ ГИС (НА ПРИМЕРЕ ОДНОГО ИЗ МЕСТОРОЖДЕНИЙ ПЕЧОРСКОЙ НГТ)
}

Некрасова Т.В., Кляжсников Д.В., Соколова Т.Ф. (Fugro-Jason)

Газо-нефтяное месторождение административно расположено на территории Ненецкого автономного округа Архангельской области, недалеко от города Нарьян-Мара.

Объектами изучения являются породы пермского возраста, терригенные отложения кунгурского яруса нижнепермского возраста (Plk) и два объекта уфимского яруса верхней перми (P2VI и P2VII).

Продуктивный территенный разрез газо- и нефтенасьщенных отложений кунгурского и уфимского ярусов, согласно результатов макро- и микроскопических исследований, а также данных гранулометрии, представлен глинистыми песчаниками и алевролитами. Коллекторами являются песчаники, редко, алевролиты с межзерновым типом емкости. Цемент смешанный - глинистый и карбонатный. Содержание карбонатного материала существенно ухудшает фильтрационно-емкостные свойства коллекторов. Песчаники в разной степени сцементированные - от рыхльх до крепко сцементированных разностей, мелко-среднезернистые, полимиктового состава, массивные и слоистые, в разной степени алевритистые с высоким содержанием глинистого материала. Для пород продуктивньгх пластов характерны рассеянная, слоистая и структурная формы распределения глинистого материала.

В зависимости от коэффищиента пористости, гроницаемости и гранулометрического состава пород, данные керна были разделены на 6 классов, что позволило оценить влияние структуры емкостного пространства пород на их фильтрационно-емкостные и водоудерживаюшие свойства. Отмечено усложнение структуры емкостного пространства песчаников по мере увеличения в их обломочной части доли мелкозернистого материала (алевритовой компоненты). Исследование физических свойств и структуры пород показало закономерное увеличение величин пористости и проницаемости и снижение остаточной воды в зависимости от размеров зерен породы - от мелкозернистых песчаников к среднезернистым и крупнозернистым, т.е. подтвердилась зависимость емкостно-фильтрационных свойств пород от их структурных особенностей.

Таким образом, среди факторов, непосредственно влияющих на пористость, проницаемость и содержание остаточной воды, влияет наличие алевритистой компоненты пород, количество и минеральный состав цемента, структура порового пространства, которые тесно связаны с обстановками осадконакопления.

Фильтрационно-емкостные и водоудерживающие свойства территенных пород с поровым типом емкости определяются колидеством, составом и формой распределения глинистого материала. Для изучения коллекторских свойств в данной работе были сделаны различные сопоставления коэффициентов пористости, проницаемости и остаточной во-

донасыщенности, которые позволили оценить кондиционные значения параметров (Кп гр $=12 \%, 14 \%$, Кпр гр=0.1 мД, 1 мД, Кво гр=0.9, 0.8 для газа и для нефти соответственно). Обращают на себя внимание высокие значения Кво, несколько первышағоцие традиционоые принимаемые для территенных коллекторов. Прежде всего, это связано с высоким содержанием глинистого материала, образовавшегося в результате вторичных процессов преобразования полевых шпатов, присутствующего в емкостном пространстве в качестве цемента и, имеющегося в виде глинистых прослоев в коллекторах слоистого типа. Высокое содержание остаточной воды в терригенных .продуктивных коллекторах пермского возраста связано; главным образом, с содержанием глинистой и алевритовой компонент.

Количество формы распределения и вещественный состав глинистого материала оказывают суммарное влияние на коллекторские свойства рассматриваемых отложений. С целью изучения этого влияния были построены сопоставления количества глинистого вещества с коэффициентами пористости, проницаемости и остаточной водонасыщенности. При этом использовались весовая, объемная и относительная глинистости. Показано, пто весь массив данных можно разделить на три грушпы коллекторов, различающихся по типу распределения глинистого материала и по граничным значениям относительной глинистости. Т.о., при выделении коллекторов требуется учитывать одновременно два критерия: по значениям коэффициента пористости (Кп гр) и коэффициента относительной глинистости(пгл.гр).

Выделение коллекторов по данным ГИС проводилось на основе качественных и обоснованных в данной работе количественных критериев.

Качественными признаками являлись: наличие сужения диаметра скважины на кривых каверномера, положительные приращения показаний на кривых микрозондов, наличие радиального градиента удельных электрических сопротивлений в показаниях разноглубинныт методах электрометрии, отрицательные аномалии СП.

Определение содержания глинистого материала в продуктивных пластах пермского возраста выполнялось по показанкям метода СП. Для оценки содержания глинистого вещества строили связи “керн-ГИС", сопоставляя величины $\alpha$ СП и ұгл. Коэффициент пористости расчитывался по показаниям акустического метода. Определение коэффициентов газонефтенасыщенности Кн терригенньх продуктивньх пластов P1k, P2VI и P2VII выполнялось по стандартной методики с помошью параметров пористости Рп и параметра насыщенбя Рн. 